\title{
浸水津波の減勢における排水路の効果 CHARACTERISTICS OF DRAINAGE CHANNELS TO ALLEVIATE TSUNAMI FLOOD DISASTERS IN COASTAL FARMLANDS
}

\author{
桐 博英 $^{1} \cdot$ 中矢哲郎 ${ }^{2} \cdot$ 丹治 肇 $^{3} \cdot$ 松島健一 $^{4}$ \\ Hirohide KIRI, Tetsuo NAKAYA, Hajime TANJI and Kenichi MATSUSHIMA

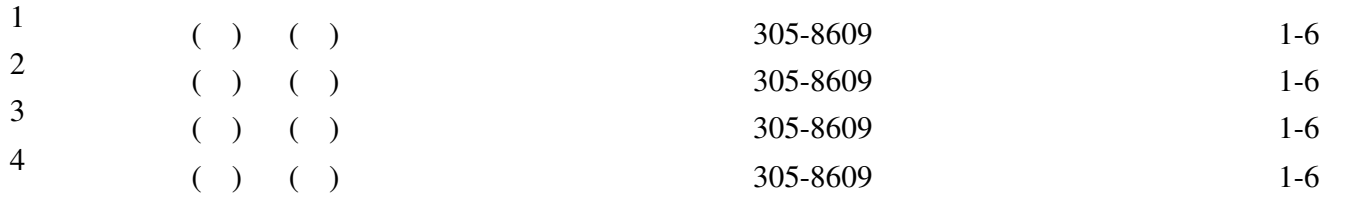

\begin{abstract}
In coastal farmlands, farm roads and farmland serve to dissipate the energy of the tsunami in stages. The role of drainage channels in spreading and draining a tsunami flood should also be considered. The energy dissipation characteristics of a drainage channel and sidewall behind a coastal levee were evaluated in this paper. The sidewall was installed either on the coastal side or on the inland side of the channel bank. A tsunami that overflowed the coastal levee washed the back slope of the levee by supercritical flow. The tsunami that reached the beginning of the inland zone generated a hydraulic jump, the location of which moved to the coastal levee. A comparison of the distribution of the bottom velocity in case of the drainage channel with or without sidewall yielded the following results: 1) In the region of small volume of overflowed tsunami, the drainage channel without sidewall dissipates the energy of the tsunami. However, a drainage channel with a wide cross section is required for a large volume. 2) The sidewall effectively dissipates tsunami energy, and the effect varies with the location of the sidewall.
\end{abstract}

Key Words: Tsunami flood, drainage channel, hydraulic model test, disaster-prevention technique, coastal farmlands

1.はじめに

2011 年の東北地方太平洋沖地震で発生した津波では， 東北地方の太平洋岸を中心に甚大な浸水被害が生じ,発 生から 3 年を迎えようとしている現在も復興に向けた 努力が続けられている .この東北地方太平洋沖地震津 波では,地震発生後に津波が仙台空港に達する状況がリ アルタイムで配信されたほか, 土木学会海岸工学委員 会と地球惑星連合が中心となって，産官学の津波調査 チームが収集した 5,900 個所にのぼる津波浸水痕デー タがとりまとめられる ${ }^{1)}$ など，多くの記録が残ってい るのが特徵である. 特に東北地方太平洋沖地震津波後 の被災状況調査や映像記録により，陸域を浸水する津 波 (以下, 浸水津波と呼引゙) に対して, 仙台東部道路と いった高盛土の道路や，海岸線と並行に仙台平野を流 れる貞山堀にも津波遡上エネルギーを減勢させる効果 があったことが推察されている．

さらに，津波の越流により海岸堤防背後に形成され た落ち堀が海岸堤防破堤の引き金になった一方で, 背 後の津波の減勢効果か認められたことが報告される ${ }^{2)}$
など，将来起こり得る巨大津波災害において，浸水津 波の減勢を図ることが減災対策の 1 つとして認識され つつある

このような中，筆者らは，震災直後から農地海岸を 中心に数次にわたる被災現場の調査を行い, 市街地と 比較して瓦礫や人的被害が少なく, 早期の復旧が期待 できる沿岸部の農業地域を津波浸水のバッファーとし て活用する浸水津波の減災手法 ${ }^{3)}$ を提案してきた . ま た，この減災手法を具体化するため，農道標高を嵩上 げすることで 2 線堤の効果を持たせたり，農地の段差 を利用したりすることで津波浸水を抑制する効果が得 られることを水理模型実験で検証するとともに ${ }^{4)}$, 被 災地域の合意形成に参画し地域復興に実践してきた ${ }^{5)}$.

しかしながら，2線堤の機能を付加させた農道の整備 は，光のコストを考えれば海岸線が短いリアス式海岸 への適用に限定されると考えるのが適当である.この ため, 本研究では, 平野部の沿岸部農地を津波浸水の バッファーに活用するため，排水路に津波の減勢機能 をもたせた場合にどの程度の効果があり，どのような 流況を呈するのかを水理模型実験で検証した . 


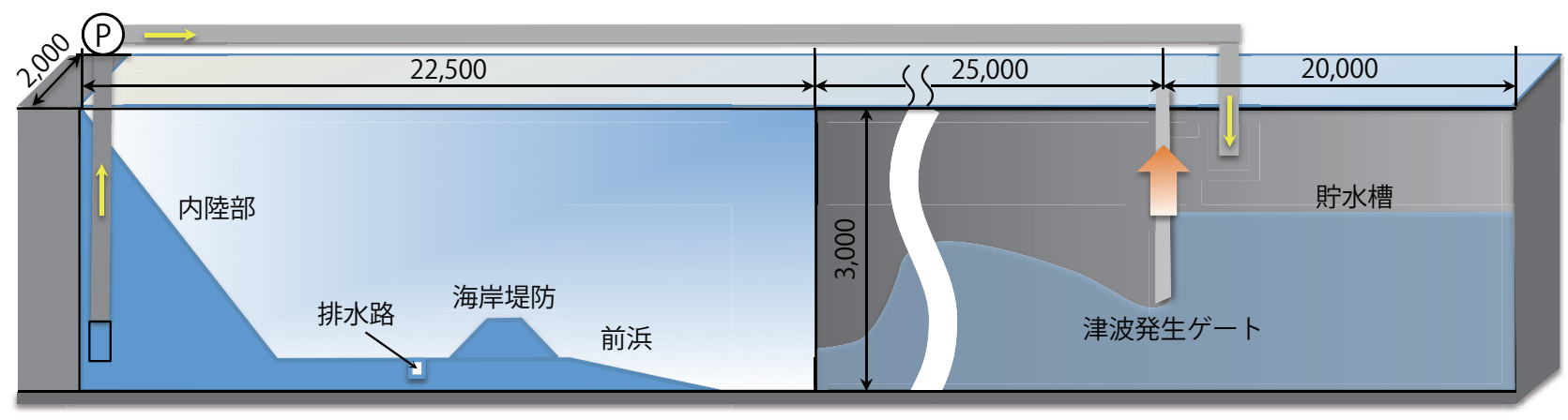

図-1 津波実験施設の概要

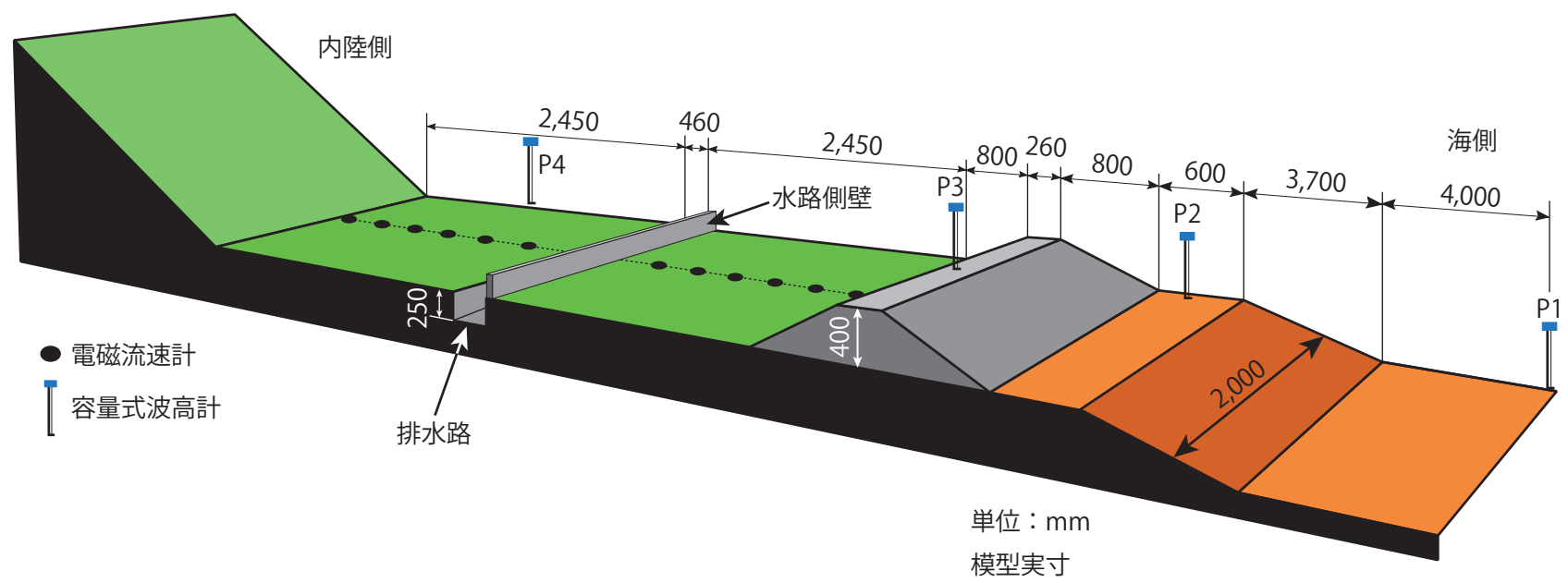

図-2 水理模型の概要

\section{2. 水理模型実験}

\section{(1) 津波実験施設の概要}

実験は , 図-1 に示す幅 $2 \mathrm{~m} \times$ 高さ $3 \mathrm{~m} \times$ 全長 $47.5 \mathrm{~m}$ の コンクリート製水槽にスルースタイプの津波発生ゲー 卜を有する津波実験施設で行った .この津波実験施設 は，津波発生ゲートを閉鎖して上流側の貯水槽に給水 し，ゲート上下流水位を所定の值に設定した後ゲートを 開放することで目標の津波を発生させる．実験終了後， 水槽下流端の模型内部に設置したポンプで貯水槽に送 水し, 次の実験に備えゲート上下流の水位を設定する . ここで, 津波発生ゲートは可能な限り短時間で開放する のが望ましいが, 水圧がかかったゲートを引き上げる 際に大きなトルクを必要とするため，ゲート開放操作 が始まるごくわずかな時間は速度を落とし，ゲートが 上昇を始めてからは $1.5 \mathrm{~m} / \mathrm{s}$ でゲートを開放した .この ため, ゲート開放直後にわずかな波が発生するが , 本装 置で発生した孤立波の波形データを確認し，津波発生 ゲート開放初期の影響はほとんどないことを確認した .

\section{（2）水理模型}

実験に使用した水理模型の概要を図-2 に示す．本模 型では, 前浜から沿岸部農地, 内陸部を模した地形に
海岸堤防および排水路を設置した .

海岸堤防の断面は, 東北地方太平洋沖地震津波で被 災した農地海岸の堤防復旧事業における堤防断面を参 考に海側，陸側法面とも 1:2 勾配とし, 堤高は使用した 津波実験施設で発生できる津波波高を勘案し $10 \mathrm{~m}$ (実 物換算値) とした。これ以降，特に断らない限り，示 す数值は実物換算したものとする．

海岸堤防背後に設けた排水路は, 津波の減勢に対す る効果を持たせることを想定して, 沿岸部の農業地帯 に見られる潮受け水路をモデルに排水路幅を $11.5 \mathrm{~m}$ と し, 海岸堤防を越えた流れが安定し, かつ内陸部の逆 勾配の影響を避けられるよう沿岸部農地の中央付近に 設置した．また，排水路の深さは，津波被災後の沿岸 部農地で復旧上の課題となっている地下水の塩水侵入 6) の防止効果を想定して水理模型で再現可能な限り深 くし，6.25m とした．また，排水路には，浸水した津波 を減勢させる目的で高さ $1.5 \mathrm{~m}$ の側壁の設置による効果 を検証したが, 長い水路延長で過度に整備コストがか かるのを避けることを考慮し，水路の海側，陸側いず れかのみに設置するものとした .

模型はフルード相似則に基づく縮尺 $1 / 25$ とし，海岸 堤防は内部を砂とジオテキスタイルで堤防形状を整形 して外側をモルタルで固定した構造とし, 前浜から内 
表-1 設定した目標津波波高

\begin{tabular}{|c|c|c|c|}
\hline ケース & 波高 I & 波高 II & 波高 III \\
\hline \hline 第1 波波高 & $10.0 \mathrm{~m}$ & $9.5 \mathrm{~m}$ & $9.0 \mathrm{~m}$ \\
\hline
\end{tabular}

陸部までの地盤は一部を鉄製のアングルで枠を作成し 表面は耐水べ二ヤ製とした．なお，模型表面には後述 する電磁流速計の設置地点を除き, 青色の耐水ペイン 卜を施した .

\section{(3) 計測項目と実験条件}

実験では，図-2に示した 4 点の水位および海岸堤防 背後 12 点の底面流速を計測し, 各データは $\mathrm{A} / \mathrm{D}$ 変換 器を介して $20 \mathrm{~Hz}$ のサンプリングレートでPC に収録し た。ここで, 水位計測には容量式波高計を用い, 海岸 堤防の堤頂中央部にはストローク $1.5 \mathrm{~m}$, 海側波高, 前 浜および排水路後方の背後地の 3 点には水路壁側にス トローク $2.5 \mathrm{~m}$ の波高計を設置した . 一方，底面流速は 模型に埋め込む形式の電磁流速計 (直径 $30 \mathrm{~mm}$ ) を使 用した . 水位および流速の計測に加えて，水理模型を 設置した長さ $22.5 \mathrm{~m}$ の観測部は片面がガラス張りであ り，側方から水理模型全体および海岸堤防部分の $2 つ$ のシーンをデジタルビデオで撮影した .

実験では，表-1に示す 3 とおりの目標津波を設定し， 予備実験で目標波高を発生できる初期水深と貯水槽水 位の関係を確認した .

予備実験の結果，図-3に示すように，津波か活芰波せ ずに海岸堤防に達する条件では堤防法面で津波がジャ ンプし, 水塊か堤防背後の地面に衝突する流況を呈する ことが分かった .このように津波が海岸堤防でジャン プする場合は, 今回の実験目的である背後地の津波減 勢状況を把握するのが困難である．このため，孤立波 の状態で沿岸部に到達した津波を前浜付近で砕波させ， 図-4に示すように津波が海岸堤防裏法を射流で越流す る状況が継続できるよう実験開始時の海域部の初期水 位を $2.5 \mathrm{~m}$ に設定した .ここで, 本論文では , 標高値は 海岸堤防法先の標高を基準とする．なお，砕波させた 津波については予備実験の水位デー夕を比較し, 複数 回の実験を行っても津波波形の再現性が保たれている ことを確認した .

実験は，表-2に示すとおり，背後地が水平である Case 1 を対照に，排水路を掘削した Case 2 , 排水路の片岸 に水路壁を設けて津波減勢効果を高めた Case 3 および Case 4 の実験条件を設定した . 実験は，上述の 3 パター ンの津波波高に対し，各ヶースで 5 回ずつ津波を発生 させ , 合計 60 回の実験を行った .

収録したデータは，1s で移動平均処理を行ったうえ で整理した。

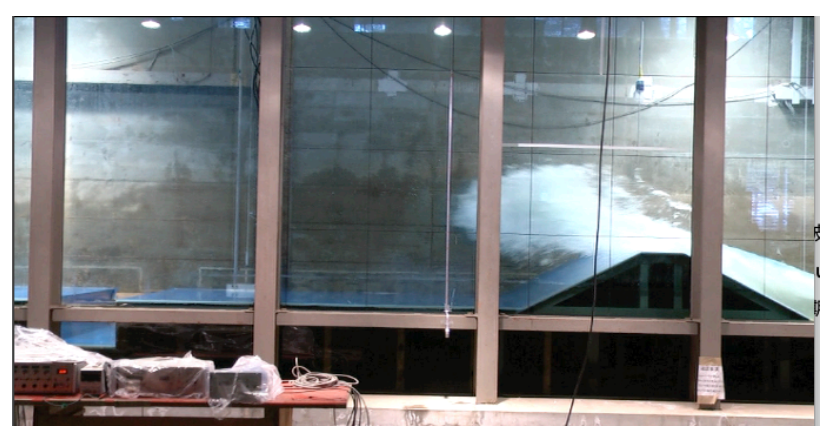

図-3 海岸堤防でジャンプする津波の状況

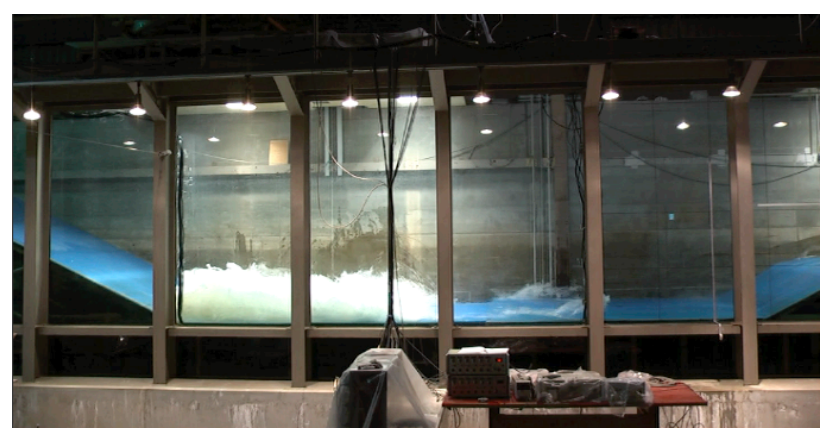

図-4 海岸堤防を津波が越流する様子

表-2 実験ケースー覧

\begin{tabular}{|c|c|c|c|}
\hline Case & 排水路 & 水路壁 & 水路壁位置 \\
\hline \hline 1 & なし & - & - \\
\hline 2 & あり & なし & - \\
\hline 3 & あり & あり & 海側 \\
\hline 4 & あり & あり & 陸側 \\
\hline
\end{tabular}

\section{3. 実験結果}

(1) 全体流況

a) 海岸堤防海側の状況

設定した目標津波波高に対し,得られた第 1 波のピー ク水位を図-5に示す .ここで,示した值は後述する水位 データと比較するため，目標津波波高に初期水位 $(2.5 \mathrm{~m})$ が加えられており，津波波高を評価するには図-5 から 初期水位を差し引く必要がある. 設定した目標波高に 対し得られた第 1 波の平均波高は, 弚れ光れ $10.27 \mathrm{~m}$ (波 高 I) , 9.62 (波高 II) および 8.92 (波高 III) であり，実 験の性質上多少のばらつきはあるものの，津波波高の 目標値をほぼ再現していると考えられる．

図-6 は,Case 1 の波高 I の条件における地点 P1 での 水位の時間変化の例を示したものである. 図-6におい て，最初の波形が津波発生ゲートで発生したものであ り，この波が海岸堤防に衝突して沖側に伝播していく のをとらえたのが 45s 以降の波形である . また，127s 以降に現れる波形は，津波発生ゲートで反射した波に よるものである.このように本実験で発生させた津波 


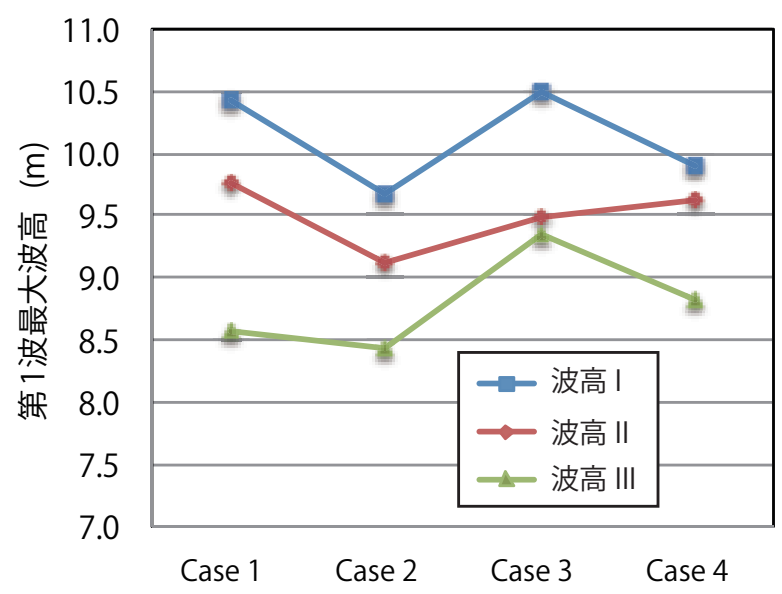

図-5 各ケースの P1 地点における第1 波の最高水位

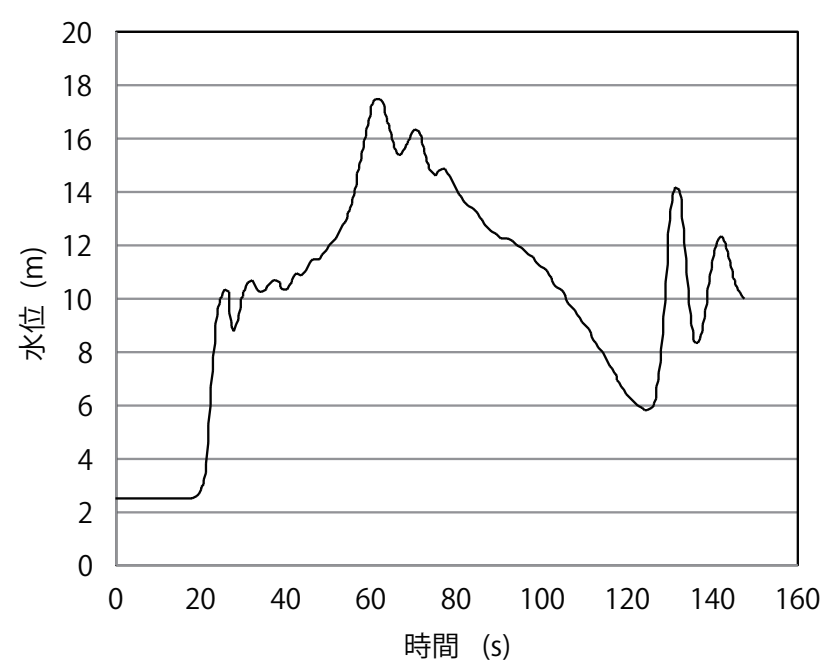

図-6 点 P1 における水位変化の例

の波高は海岸堤防の天端高を大きく超えるものではな いが, これが海岸堤防で反射して沖側に伝播すること で水位が上昇し, 海岸堤防海側の水位が高い状態が安 定して継続する。

各実験ヶースにおける海岸堤防で反射した津波によ る最高水位を図-7に示す．海岸堤防で津波が反射する ことで, 入射した津波波高の約 1.7 倍程度まて堤防海側 の水位が上昇することが分かる．また，最高水位を記 録する際の津波波形は津波第 1 波と比較して水面の動 摇が少ないため, Case 4 の波高 I を除いて , 各ケースに おける最大水位の間隔がほぼ均等であることが分かる .

各実験ケースにおける海岸堤防越流水深をプロット したのが図-8である.津波が堤防を越流する際に海岸 堤防上で限界流を生じることから，水位変動が少なく 安定した状態を呈する.沖側の波高は目標津波の差異 が明瞭でない場合も見られたが，海岸堤防天端の越流 水深を評価する限り，発生させた津波により越流状態 を区別できていると判断した .

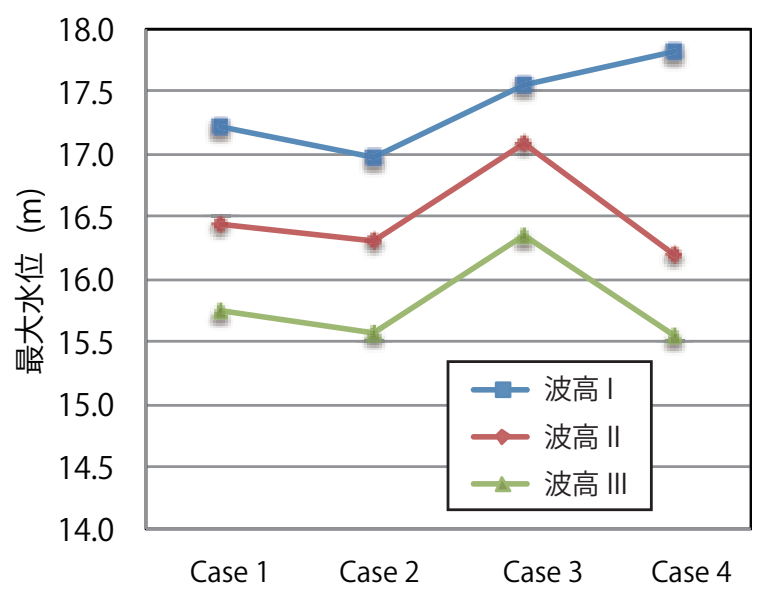

図-7 各ケースの P1 地点における最高水位

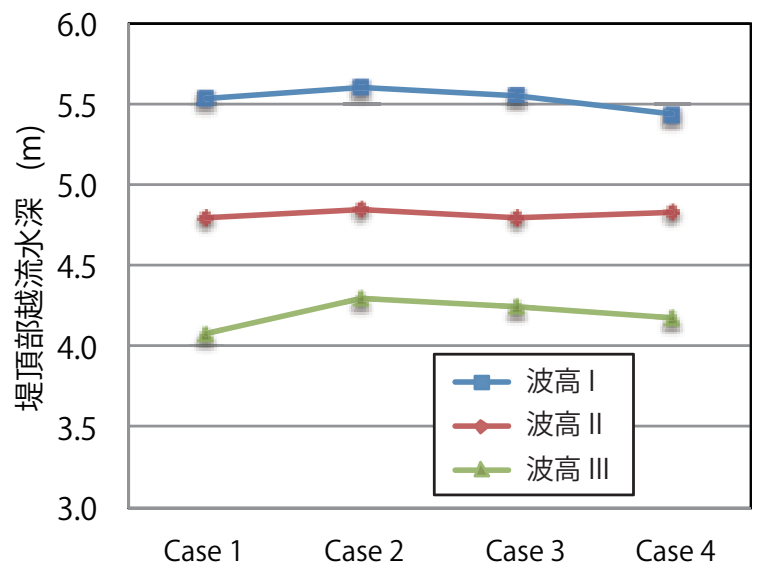

図-8 各ケースの海岸堤防越流水深

b) 浸水津波の流況

海岸堤防を越流した津波は，図-4で見られたように， 堤防裏法および堤防背後地を射流で流下したあと内陸 部に達し，ここで発生した跳水が海側へ移動しながら 最終的に海岸堤防に到達する

本論文では, 海岸堤防背後に浸水した津波の減勢効 果を検証することを目的としているため，実験で得ら れた流速データのうち, 跳水が生じる前のものだけを 対象として以下に整理した .ここで, 実験では測定レ ンジ $3 \mathrm{~m} / \mathrm{s}$ の電磁流速計を使用していたが, 海岸堤防に 近い 3 つのセンサーで測定レンジを越える流速を記録 した .これらのデータを詳細に検証したところ, $3.5 \mathrm{~m} / \mathrm{s}$ 程度までは測定した流速值が線型に上昇するのを確認 し，データとして採用した。ただし，最も海岸堤防に 近い $0 \mathrm{~m}$ 地点のセンサーでは波高 I で流速が測定限界を 振り切っているものが見られたため, 当該地点の流速 は参考値である .

波高 I , II および III での背後地の流速分布を図-9〜 図-11 に示す .ここで, 各マーカーに示したエラーバー は , 5 回のデータの標準偏差を示している. 実験值のば らつきは, Case 4 の排水路直後の計測点を除き，いず れも平均值の 5\%以内に収まっており実験の再現性に問 


\section{(2) 排水路掘削による効果}

図-9〜図-11 で青線 (Case 1) は背後地が水平であり， 赤線 (Case 2) か排水路が掘削された結果である. Case 1 と 2 の比較では, 越流水深が最も大きい波高 I で両者 に違いはなく排水路掘削の効果は認められないが , 波高 II で $1 \mathrm{~m} / \mathrm{s}$ 程度, 波高 III で $2 \mathrm{~m} / \mathrm{s}$ 程度排水路の掘削が陸 側 (距離 $72 \mathrm{~m}$ 以降) の流速を減少させている .ここで， $25 \mathrm{~m}$ から $50 \mathrm{~m}$ 地点までの流速のプロファイルを見ると， いずれの越流条件でも $40 \mathrm{~m}$ 地点と $50 \mathrm{~m}$ 地点で流速の值 に大きな違いは見られず，50m 地点では定常に近い状 態になっていると推測できる .このときの流速は, 波高 I で $14.2 \mathrm{~m} / \mathrm{s}$ ，波高 II，III が光れ光れ $13.8 \mathrm{~m} / \mathrm{s} ， 13.3 \mathrm{~m} / \mathrm{s}$ であり，今回の模型で再現した排水路では，排水路近 傍の流速を $14 \mathrm{~m} / \mathrm{s}$ 以下に落とすことができれば排水路 掘削による津波減勢効果が得られることが分かった .

(3) 水路壁の効果

a) 波高 I の場合

図-9 おいて，排水路を掘削しただけの Case 2 と水路 壁を有する Case 3 および 4 を比較すると，水路壁の設 置により流速が減少しているのが確認できる . 排水路 背後 (堤防法尻から $84 \mathrm{~m}$ 地点以降) の流速と流速の減 少率を表-3 に示す．ここで水路壁を排水路の海側に設 置した Case 3 では, 排水路直後の $84 \mathrm{~m}$ 地点で $6.6 \%$ の 減少を記録するが, 弚の後, 減少割合は水路壁を設置し ないCase 2 との差は見られず, 当該条件では水路壁設 置の効果が排水路近傍に限られることが分かる .これ は，海岸堤防を射流で流下した津波が水路壁に衝突し， 一時的に流向を上向きに変えるものの津波を減勢する には至らず, 上昇した水位で生じる位置エネルギーが炎 のまま運動エネルギーに変換されるためと考えられる．

一方，水路壁を陸側に設置した Case 4 では，排水路 直後の流速の減少率は $18 \%$ であり, 光れ以降も $12 \%$ を

表-3 排水路背後の流速と減少割合 ( 波高 I)

\begin{tabular}{|c|c|c|c|}
\hline $\begin{array}{c}\text { 堤防法尻から } \\
\text { の距離 }(\mathrm{m})\end{array}$ & Case 2 & Case 3 & Case 4 \\
\hline \hline 84 & 12.26 & 11.45 & 9.97 \\
& - & $6.6 \%$ & $18.7 \%$ \\
\hline 94 & 12.27 & 12.42 & 10.72 \\
& - & $-1.3 \%$ & $12.6 \%$ \\
\hline 104 & 12.55 & 12.34 & 10.93 \\
& - & $1.6 \%$ & $12.9 \%$ \\
\hline 114 & 12.12 & 12.38 & 10.35 \\
& - & $-2.2 \%$ & $14.6 \%$ \\
\hline 124 & 12.26 & 12.40 & 10.50 \\
& - & $-1.2 \%$ & $14.3 \%$ \\
\hline
\end{tabular}

上段は流速 $(\mathrm{m} / \mathrm{s})$ ，下段は Case 2 からの 流速の減少割合を示す。

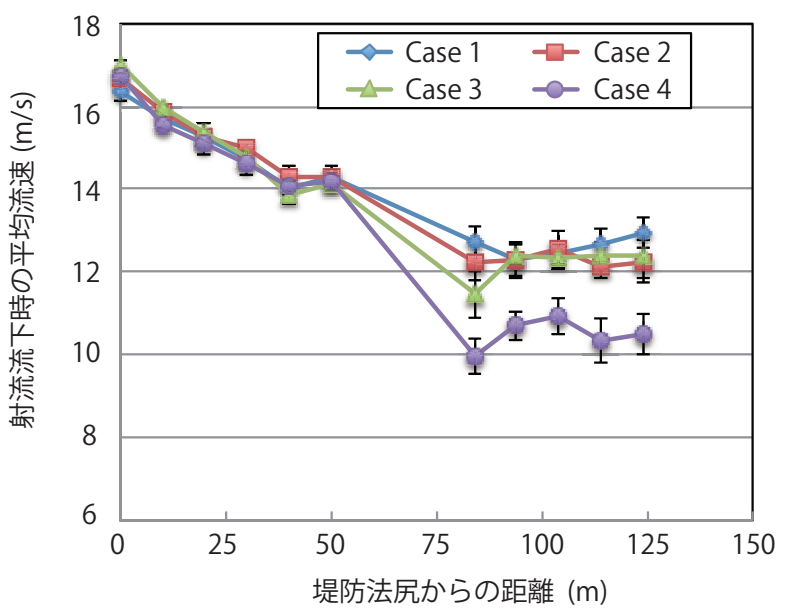

図-9 浸水津波の流速分布の比較（波高 I)

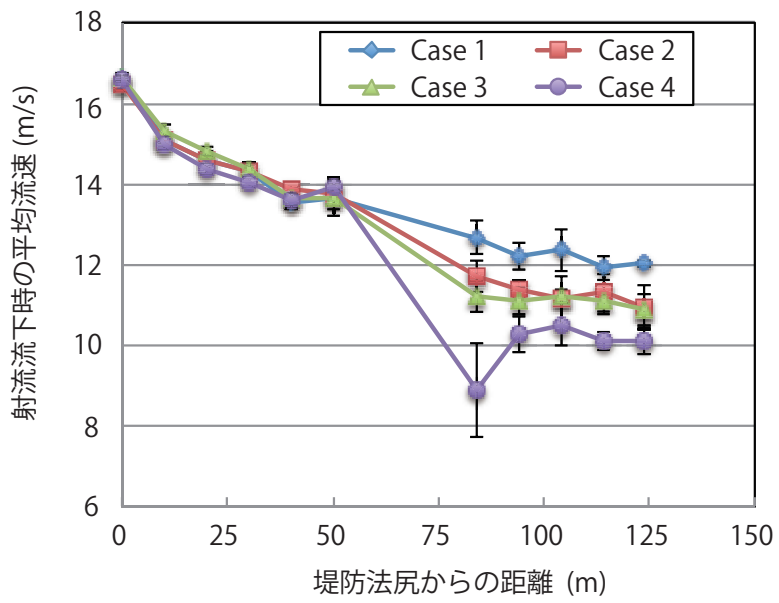

図-10 浸水津波の流速分布の比較（波高 II）

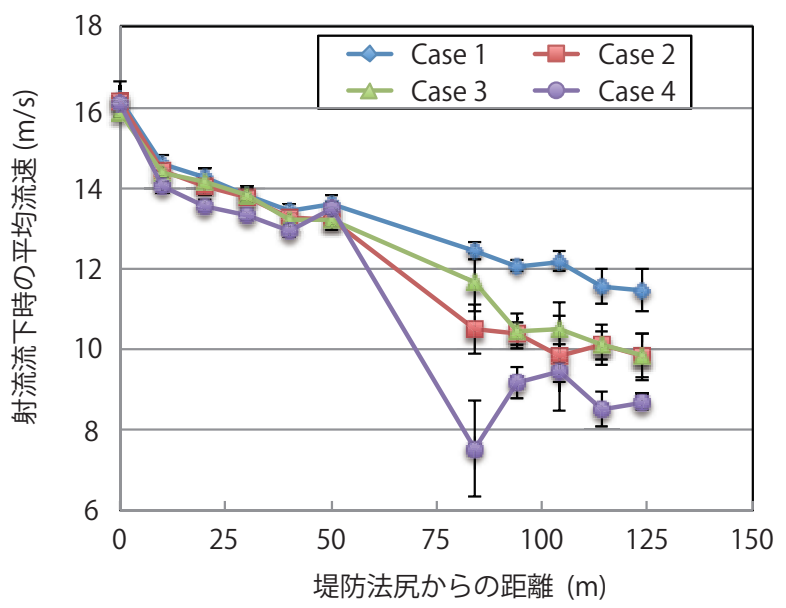

図-11 浸水津波の流速分布の比較( 波高 III) 
越える効果が継続している．

b) 波高 II, III の場合

波高 II ，III における排水路背後の流速の減少割合を 弚れ光れ，表-4および表-5に示す．これらの条件でも Case 2 と 3 で流速の減少に明瞭な差は見られない .こ れは, 波高 Iでは高速の津波が水路壁に衝突し, Case 3 では上向きに流速を変え, Case 4 では上向きに加え排 水路内部に向く流机に分かれる流況を呈するのに対し， 波高 II ，III では，Case 3 で津波が水路壁に衝突するこ とでジャンプするものの，減勢効果の多くが排水路の 掘削によるためと考えられる .

一方，水路壁を陸側に設けた Case 4 では $84 \mathrm{~m}$ 地点で 24\%を越える大きなな減少率を記録し, 弚れ以降も波 高 I ほどではないものの流速の減少が維持される . こ の高い減少率は，陸側に設けた水路壁が陸側に向かう 流れを乱しているためと考えられる．これは，図-10， 図-11 で見られたように，波高 II，III の Case 4 で排水 路背後の流速のばらつきが大きかったことからも推察 される .

以上のことから，排水路の側壁を高くした場合の効 果は，水路壁を海側に設置した場合は効果が小さいと いえる。しかし，側壁を陸側に設置した場合は，排水 路の掘削に加えてさらに4〜10\%程度の流速の減少か認 められ，これか偝後でも維持されることがわかった .

\section{4. まとめ}

本研究では, 沿岸部の農地に浸水津波の遡上を抑制 する効果を高めることを目的に，水理模型実験により 海岸堤防背後に設けた排水路の遡上津波の減勢効果を 検証し，以下の結論を得た .

・津波越流量が大きくない場合は排水路の掘削で咸 勢効果が得られる

・越流量が大きい津波では排水路断面を大きくする 必要があるが, 水路壁を高くすることで咸勢効果 を高めることができる．

- 排水路の掘削に加えて水路壁を陸側に設置するこ とで聿波減勢効果を大きくすることができるが，排 水路幅を十分に確保できる場合は水路壁の効果は 小さい.

この津波減勢効果が得られる流速の限界值は排水路幅 や深さにより変化すると考えられ, 排水施設群の整備 コストと効果の関係を明らかにするにはさらなる検証 が必要であるが, これらの評価は今後の課題である .

\section{参考文献}

1) The 2011 Tohoku Earthquake Tsunami Joint Survey Group: Nationwide field survey of The 2011 off the Pacific Coast of
表-4 排水路背後の流速と減少割合( 波高 II)

\begin{tabular}{|c|c|c|c|}
\hline $\begin{array}{c}\text { 堤防法尻から } \\
\text { の距离倠 (m) }\end{array}$ & Case 2 & Case 3 & Case 4 \\
\hline 84 & $\begin{array}{c}11.70 \\
-\end{array}$ & $\begin{array}{l}11.21 \\
4.2 \%\end{array}$ & $\begin{array}{c}8.90 \\
24.0 \%\end{array}$ \\
\hline 94 & $\begin{array}{c}11.37 \\
-\end{array}$ & $\begin{array}{l}11.09 \\
2.5 \%\end{array}$ & $\begin{array}{l}10.28 \\
9.7 \%\end{array}$ \\
\hline 104 & $\begin{array}{c}11.15 \\
-\end{array}$ & $\begin{array}{r}11.21 \\
-0.5 \%\end{array}$ & $\begin{array}{l}10.50 \\
5.8 \%\end{array}$ \\
\hline 114 & $\begin{array}{c}11.31 \\
-\end{array}$ & $\begin{array}{l}11.13 \\
1.6 \%\end{array}$ & $\begin{array}{l}10.11 \\
10.6 \%\end{array}$ \\
\hline 124 & $\begin{array}{c}10.93 \\
-\end{array}$ & $\begin{array}{l}10.89 \\
0.3 \%\end{array}$ & $\begin{array}{l}10.10 \\
7.6 \%\end{array}$ \\
\hline
\end{tabular}

表-5 排水路背後の流速と減少割合（波高 III）

\begin{tabular}{|c|c|c|c|}
\hline $\begin{array}{c}\text { 堤防法尻から } \\
\text { の距離 }(\mathrm{m})\end{array}$ & Case 2 & Case 3 & Case 4 \\
\hline \hline 84 & 10.47 & 11.65 & 7.53 \\
& - & $-11.2 \%$ & $28.1 \%$ \\
\hline 94 & 10.38 & 10.45 & 9.15 \\
& - & $-0.7 \%$ & $11.8 \%$ \\
\hline 104 & 9.81 & 10.48 & 9.43 \\
& - & $-6.8 \%$ & $3.9 \%$ \\
\hline 114 & 10.10 & 10.10 & 8.51 \\
& - & $-0.1 \%$ & $15.7 \%$ \\
\hline 124 & 9.82 & 9.85 & 8.51 \\
& - & $-0.3 \%$ & $11.6 \%$ \\
\hline
\end{tabular}

上段は流速 $(\mathrm{m} / \mathrm{s})$, 下段は Case 2 からの

流速の減少割合を示す。

Tohoku Earthquake Tsunami, 土木学会論文集, B2(海岸工 学), Vol.67, No.1, pp.63-66, 2011.

2) 常田賢一, 谷本隆介 : 2011 年東北地方太平洋沖地震におけ る土盛構造の耐津波特性およひ落堀の形成特性, 土木学会論 文集 ,A1(構造·地震工学), Vol.68, No.4, pp.I_1091-I_1112, 2012.

3) 毛利栄征, 丹治 肇 : 海岸堤防の後背農地による津波減勢 一減災農地の考え方と提案一, 農村工学研究所技報, 第 213 号, pp.105-116, 2012.

4) 桐博英, 丹治肇, 中矢哲郎: 後背農地を活用したレベル 2 津波の浸水抑制効果の水理模型実験，土木学会論文集， B2(海岸工学), Vol.68, No.2, pp.I_1311-I_1315, 2012.

5) 福与徳文, 山本徳司, 桐 博英 : 岩手県大船渡市吉浜地区に おける農地復興計画作成支援 -減災農地と地域復興計画- , 農村工学研究所技報, 第 213 号, pp.287-295, 2012.

6) 中矢哲郎, 丹治肇, 桐博英 : 農地・排水系施設の復旧状況 からみる 2011 東日本地震津波による塩害長期化の実態, 土 木学会論文集, B1(水工学), Vol.69, No.4, pp.I_1471-I_1476, 2013.

( 2013.9.30 受付) 